\title{
EDITORIAL
}

\section{The 2013 ACR Meeting: Mad Macs at the Marina}

\author{
David S Pisetsky ${ }^{1,2}$
}

San Diego, the site of the 2013 American College of Rheumatology (ACR) meeting, sits like a vision of the future at the far tip of the United States, just up the road from Mexico and smack next to the Pacific Ocean. Like its siblings in California, Los Angeles and San Francisco, San Diego is one of the geographic last stops of the American dream. For centuries, people have trekked across the country to find a better life in the Golden State, searching for jobs and opportunity but also a Mediterranean climate replete with palm trees and orange groves, cool breezes that sweep in from the ocean, and brilliant sunsets where gulls circle overhead to call out the arrival of night. What a great place to be! It is so beautiful that you forget the smog, landslides, earthquakes, congestion, an antiquated tax system, a mayor gone wild, and fractious politics that recently have made the Golden State sometimes less than golden.

Housing a worldwide congress requires a big venue with lots of space. The San Diego Convention Center is gigantic, stretching probably a mile along the bay. I would say that it is as big as a battleship but that would not be true since the convention center is right next to the USS Midway (a carrier not a battleship) and the convention center looks far, far larger. I honestly have never seen corridors so long nor spent so much time walking from room to room at a meeting. I wished that the city or county leaders had put the light rail system with its snappy red cars inside the convention center instead of outside on Harbor Boulevard. Its location there would have made the transit from session to session much quicker, with the clanging of warning bells-ding ding ding-as the train approached jazzing up the proceedings.

A convention hall the size of San Diego's has its plusses and minuses, although, remarkably, even though the center had a gazillion square feet of space (actually 615,700, according to Wikipedia), some of the sessions were held in the nearby Hilton with its shining marble façade and rooms with romantic names like the Indigo or Sapphire.

\footnotetext{
Correspondence: dpiset@acpub.duke.edu

${ }^{1}$ Medical Research Service, Durham Veterans Medical Center, 508 Fulton Street, Durham, NC 27705, USA

2Department of Medicine, Duke University Medical Center, Durham, NC 27705, USA
}

Sounds much better than $6 \mathrm{~A}$ or 33A. On the plus side, at the convention center, there were lots of really big rooms, the corridors were as wide as the Champs-Élysées, and you could get great exercise transiting from the plenary session to a Meet the Expert soiree.

On the minus side, the size of the convention center made it difficult to bump into people, literally and figuratively. Meetings used to be a place to see friends in the crowded buzz of a hotel lobby. Now, with the mammoth size of these affairs, you either have a "Where's Waldo?" search or have intelligently used email to prearrange a visit assuming you could locate the place in the convention center. Spontaneity and coincidence are things of the past, and the excitement that comes with the chance meeting of a friend or trainee as you both walk down the same hall is a rare occurrence. Social media is supposed to be the answer to this type of isolation and, while you could try to stay connected by Facebook, Flickr, LinkedIn, and whatnot, human contact is at the heart of a great meeting.

While I may have been a bit overwhelmed by the venue, I found solace in the sessions. The science of rheumatology is forever ascending and is entering an exciting era as genetics, genomics, and epidemiology are providing increasingly detailed and vivid pictures of what happens in disease. The analysis, whether of patient, population, or plasma, is ever more refined (or granular, in popular lingo) and intriguing, but what we are learning from all these studies should be obvious: life is not simple. The complexity of life processes-both physiological and pathologicalis variously fascinating, challenging, daunting, intimidating, mystifying, and awe-inspiring. When I did locate a friend to discuss some session, I often heard that the science presented was incremental and not much new. I disagree. There was an incredible amount that was new but none of it is simple. Indeed, it is gloriously complicated, elaborate, and ornate, as I learned attending lectures at the ACR meeting.

For quite a few years, the field of rheumatology has used language that has been very appealing but not really accurate. At the top of the list is the concept of targeted therapy, as it refers, in particular, to monoclonal 
antibodies to cytokines. Such therapies were supposed to be like "a surgeon's knife" and to vaporize an offending cytokine with "laser-like precision". These agents can be wonderfully effective, but eliminating the target can have extraordinarily diverse consequences because the target has so many actions.

Consider the role of cytokines in inflammation. IL-6 is a pleotropic mediator whose elimination or reduction can be accomplished with tocilizumab, an antibody to the IL-6 receptor that has been approved for the treatment of several diseases, including rheumatoid arthritis (RA). IL-6 is a fine target to block inflammation but the action of IL-6 is anything but simple because it can signal cells in two ways. The first is via binding to the IL-6 receptor itself, which is expressed in a limited number of cell types, including the liver and certain immune cells. The second is via the formation of a complex with soluble IL-6 receptor that in turn can bind to gp120, which is expressed on a wide variety of cell types. This system was elegantly discussed by Simon Jones from Cardiff University.

Targeting IL-6 signaling (via an antibody to the receptor, an antibody to the cytokine, or soluble construct of gp130) thus has potentially a host of actions, and therapy with tocilizumab, like that with any anti-cytokine, can do many, many things in addition to putting the brakes on C-reactive protein production or messing with IL-17 cells. A plethora of functional and metabolic consequences can ensue when IL-6 signaling is diminished, and it will be fascinating to see how these issues play out in the treatment of diseases such as lupus and diabetes among others.

Cell lineages are also exploding in their complexity. While we are accustomed to the diversity of T-cell and B-cell populations, immunologists are now subdividing the macrophage family, starting with the M1 and M2 subtypes, as described in a lecture by David Mosser of the University of Maryland. These two subtypes differ from each other in markers, conditions for induction, and putative functional roles. M1 cells are the familiar inflammatory macrophages that can serve as a bulwark in host defense or a menace in disease pathology depending on setting. In contrast, their relatives, the M2 macrophages, have regulatory properties that can suppress inflammation and promote repair.

While the histological finding of macrophages has long been viewed as evidence of ongoing inflammation in the tissue, the situation may be more complex since some of those macrophages may in fact mediate repair or quash the mischief induced by other immune cell types. Remember that $\mathrm{T}$ cells started with $\mathrm{CD} 4$ and $\mathrm{CD} 8$ populations. Now look what happened with $\mathrm{T}$ cells with plasticity forever making cell classification and identification technically and intellectually challenging.
Complexity is rampant in the realm of genetics. I was intrigued by an abstract on genetic and environmental risk factors in families with multiple affected members with RA. This study came from Jiang and colleagues at the Karolinska Institutet and took advantage of the fabulous registries in Sweden. The bottom line of this study is that, in families with multiple affected members, known risk factors-including gene regions identified from big genome-wide association studies (GWASs) account for only a small amount of the disease risk. These findings are surprising and at variance with the simple prediction that multiplex families would have an extra load of the risk factors identified in epidemiologic or genetic study. At minimum, these findings suggest that other genes, not identified in current large population-based studies, may be at play and are tilting family members in the direction of autoimmunity.

The implications of this study are large in terms of the conduct of genetic analyses of complex human diseases. I am reminded of the famous quotation by Tolstoy: "All happy families are alike. Each unhappy family is unhappy in its own way". Perhaps the same is true for the risk for RA and each family will have RA its own way to become unhappy. In the face of this situation, some may question the value of the large GWASs whereas others see a huge opportunity in deep sequencing of the genomes of these families.

Craig Venter, who gave a glimpse of the future about artificial life in his opening lecture (a tour de force that left the audience dazzled), no doubt has the technical know-how and moxie for an assault on the genetics of RA one family at a time. Whether there are funds for such an enterprise is another question. In the aftermath of the government shutdown and the ever-declining resources of the National Institutes of Health, the prospects for big scienceincluding a Manhattan Project for more geneticsmay be uncertain. Genetics studies are now like a house-to-house combat in which each family is a battle unto itself to conquer genetic complexity.

After a day near the convention hearing lectures, gazing at posters, or visiting the exhibits, a stroll around town is always refreshing, but I must say the environment in downtown San Diego is a tale of two cities. Surrounding the convention center in the Marina district are a bevy of new hotels juxtaposed with high-rise apartments with curved profiles and glass façades that look blue, bronze, and gold depending on time of day and angle of the sun. These beautiful buildings soar and they gleam but they also look stark, almost sterile, forbidding and austere, more like sculptures than habitats since there is hardly a sign of the people who live there. No laundry hanging out the windows or children riding their tricycles in the courtyards. There is a ghost town 
look to these apartment complexes even if they house thousands.

The Gaslamp District is another story. There, San Diego pulses with the nitty-gritty of life. The Gaslamp District is the historic center of San Diego and, now after a 20th-century renovation, has the feel of the New Orleans French Quarter but more contrived and less organic in its development. It is also less steamy and dank than the Crescent City, and thankfully there are no horses to give the atmosphere a pungent lift. It is as if the San Diego civic parents, recognizing the impersonal appearances of the high rises, created an urban petri dish and cultivated some life in the environs of Fifth Avenue and Broadway.

In the Gaslamp District, you can get on a bicycle taxi with flashing green, yellow, and blue lights as the driver, with a boombox soundtrack, peddles you up the street to have a taco at Funky Garcia's, take a few puffs at Fumari Hookah lounge, or get some new body art at Nothing Sacred Tattoo.

One night, on my way back to my hotel after a dinner of grilled mahi-mahi at Spike Africa's restaurant, a homeless man came up to me and asked for $\$ 20$. He had thick shaggy blond hair and skin with a burnt umber tint from panhandling in the bright California sun. He said I should think of the $\$ 20$ as an investment. Suffice it to say, I didn't. That was the second best appeal, after the man who asked me for a bucket for a bucket of fried chicken from Ralphs supermarket on G Street. If nothing else, these were very thoughtful requests, perhaps the vanguard of a strategy to panhandle to target.

While I can bemoan the sight of a man peeing on the wall of the Nordstrom store at Horton Plaza, I felt at home in the Gaslamp District. This is what life is all about-grimy, strident, vulgar, and complicated - where systems to regulate behavior fizzle and misfire and people dress up like Dracula, get drunk, and howl in the night in pre-Halloween revelry.

Investigators in rheumatology, like every other specialty, like to think in orderly ways and to populate their PowerPoint slides with nice round cells conveniently labeled and a spate of arrows going this way and that way to predict just what will happen when an antibody snarfs up some cytokine or a nib hits a kinase and the system is supposed to shut itself down. Of course, in the animal model or in the patient, sometimes nothing happens, disease worsens, or the white count goes in the wrong direction and the cholesterol rises instead of falls. In the joint, an MI macrophage is a mad man and, instead of looking like a nice round circle spotted with CD80/86, such a macrophage looks, on a micro scale, like the bouncer I saw at a bar, a big bruiser of a fellow who had his orange mohawk gelled upright over a shaved head with a tattoo design that looked like livedo reticularis. Indeed, with ink, not even the signs of vasculitis are sacred.

As I learned in San Diego, the convention center has theory, all neat and clean. The street has reality. As rheumatology progresses, the street with all its noise and complexity is where the action is and we better learn to walk down on it.

\section{Competing interests}

The author declares that he has no competing interests.

\section{Published: 23 Dec 2013}

\section{Suggested reading}

1. Cohen HB, Mosser DM: Extrinsic and intrinsic control of macrophage inflammatory responses. J Leukoc Biol 2013, 94:913-919.

2. Garbers C, Thaiss W, Jones GW, Waetzig GH, Lorenzen I, Guilhot F, Lissilaa R, Ferlin WG, Grötzinger J, Jones SA, Rose-John S, Scheller J: Inhibition of classic signaling is a novel function of soluble glycoprotein 130 (sgp130), which is controlled by the ratio of interleukin 6 and soluble interleukin 6 receptor. J Biol Chem 2011, 286:42959-42970.

3. Jiang X, Frisell T, Askling J, Klareskog L, Alfredsson L, Källberg H: To which extent may the familial risk of rheumatoid arthritis be explained by established risk factors? Arthritis Rheum 2013, 65(Suppl):S1025.

4. Jones SA, Scheller J, Rose-John S: Therapeutic strategies for the clinical blockade of IL-6/gp130 signaling. J Clin Invest 2011, 121:3375-3383.

5. Karas BJ, Jablanovic J, Sun L, Ma L, Goldgof GM, Stam J, Ramon A, Manary MJ, Winzeler EA, Venter JC, Weyman PD, Gibson DG, Glass Jl, Hutchison CA III, Smith HO, Suzuki Y: Direct transfer of whole genomes from bacteria to yeast. Nat Methods 2013, 10:410-414.

6. Navarro G, Taroumian S, Barroso N, Duan L, Furst D: Tocilizumab in rheumatoid arthritis: a meta-analysis of efficacy and selected clinical conundrums. Semin Arthritis Rheum 2013.

7. Rose-John S: IL-6 trans-signaling via the soluble IL-6 receptor: importance for the pro-inflammatory activities of IL-6. Int J Biol Sci 2012, 8:1237-1247.

10.1186/ar4419

Cite this article as: Pisetsky: The 2013 ACR Meeting: Mad Macs at the Marina. Arthritis Research \& Therapy 2013, 15:130 